\title{
Hubungan Mutu Buah dan Curah Hujan Terhadap Kandungan Asam Lemak Bebas pada Minyak Kelapa Sawit
}

\author{
Relationship Between Fruit Quality and Precipitation on Free Fatty Acids Content of Palm Oil \\ Imdad Julian Purwanto ${ }^{1}$, Edi Santosa ${ }^{*}$ \\ ${ }^{1}$ Departemen Agronomi dan Hortikultura, Fakultas Pertanian, Institut Pertanian Bogor \\ (Bogor Agricultural University), J1. Meranti, Kampus IPB Darmaga, Bogor 16680, Indonesia \\ Telp.\&Faks. 62-251-8629353 e-mail agronipb@indo.net.id \\ *Penulis untuk korespondensi: edisang@gmail.com
}

Disetujui 14 November 2016/ Plublished online 8 Desember 2016

\begin{abstract}
Research was conducted in order to study relationship between harvest management and content of free fatty acid (FFA). Activities were carried out from February to June 2014 in North Sumatera Province. Effects of fruit quality and precipitation on FFA were analyzed by using multiple linier regression models. Results showed that FFA content significantly affected by percentage of delayed-processed bunches (restan) $(P$ value $=0.045)$. Increasing level of delayed-processed bunches at rate of $1 \%$ increased FFA level of $0.001 \%$. Percentage of over ripe, unripe and under ripe fruits and precipitation did not significantly affect FFA level. This research implies that control of delayed-processed bunch is important to maintain level of FFA.
\end{abstract}

Keywords: crude palm oil, free fatty acid, general linier model, restan-fruit

\begin{abstract}
ABSTRAK
Kegiatan penelitian dilaksanakan untuk menganalisis faktor yang mempengaruhi kandungan asam lemak bebas $(A L B)$ di kebun kelapa sawit. Faktor yang dianalisis adalah kualitas buah dan curah hujan hubungannya dengan kandungan ALB. Kegiatan dilaksanakan pada bulan Februari sampai Juni 2014 di Provinsi Sumatera Utara. Analisis data dilakukan menggunakan model regresi linier berganda. Hasil menunjukkan bahwa kenaikan persentase buah restan berpengaruh nyata $(P$ value $=0.045)$ terhadap kenaikan kadar ALB pada taraf 10\%. Kenaikan 1\% jumlah buah restan akan menaikkan ALB sebesar $0.001 \%$. Persetase buah over ripe, buah unripe dan buah under ripe tidak berpengaruh nyata terhadap kenaikan ALB. Hal tersebut diduga karena proporsi yang sangat kecil. Demikian juga curah hujan, tidak berpengaruh nyata terhadap kandungan ALB.
\end{abstract}

Kata kunci: asam lemak bebas, buah restan, CPO, model linier berganda 


\section{PENDAHULUAN}

Kelapa sawit (Elaeis guineensis Jacq.) adalah tanaman yang memiliki nilai ekonomi yang tinggi. Di Indonesia kelapa sawit memiliki arti penting di Indonesia karena mampu menciptakan kesempatan kerja bagi masyarakat sebagai pengelola sumber devisa negara. Kelapa sawit menghasilkan minyak nabati yang memiliki kadar kolesterol rendah, bahkan tanpa kolesterol (Sastrosayono, 2003). Luas areal perkebunan kelapa sawit pada tahun 2012 mencapai 9.57 juta ha dan mencapai 10.01 juta ha pada tahun 2013 . Produksi kelapa sawit pada tahun 2012 mencapai 26.01 juta ton dan pada tahun 2013 produksi kelapa sawit mencapai 27.74 juta ton (Ditjenbun, 2013).

Minyak yang berasal dari kelapa sawit ada 2 macam yaitu dari daging buah (mesocarp) yang dihasilkan melalui proses perebusan dan pemerasan dikenal sebagai minyak sawit kasar atau crude palm oil (CPO) dan minyak yang berasal dari inti sawit (endocarp) dikenal sebagai minyak inti sawit atau palm kernel oil (PKO). Umumnya CPO dan PKO digunakan untuk produk pangan sebagai minyak goreng. Untuk menghasilkan minyak goreng yang memiliki kualitas tinggi dilakukan proses rafinasi. Proses rafinasi CPO dan PKO dilakukan dengan 3 tahap yaitu degumming, bleaching dan deodorisasi (Hasibuan dan Nuryanto, 2011).

Semakin meningkatnya permintaan pasar terhadap CPO di Indonesia, tuntutan untuk peningkatan kualitas dan kuantitas produk pun semakin meningkat. Secara umum kualitas CPO ditentukan oleh kandungan asam lemak bebas (ALB). Asam lemak bebas terbentuk karena proses oksidasi dan hidrolisa enzim selama pengolahan dan penyimpanan. Kandungan ALB yang dihasilkan dipengaruhi oleh kualitas pemanenan. Pemanenan pada saat buah dalam keadaan lewat matang akan meningkatkan asam lemak bebas (ALB) atau free fatty acid (FFA) dan menurunkan mutu minyak. Panen saat TBS buah belum matang manghasilkan ALB rendah, tetapi akan mengasilkan rendemen minyak sawit yang rendah sehingga dapat menurunkan produksi (Fauzy et al., 2012). Pengelolaan kadar ALB yang tepat merupakaan hasil dari manajemen panen dan pasca panen yang baik dan ketepatan dalam pengelolaannya.

\section{BAHAN DAN METODE}

Penelitian dilakukan pada bulan Februari hingga Juni 2014, di Kebun Rambutan yang terletak di Kabupaten Serdang Bedagai Provinsi
Sumatera Utara. Data primer diperoleh melalui pengamatan atau wawancara secara langsung di lapangan yang berkaitan dengan faktor-faktor yang mempengaruhi fluktuasi kandungan ALB pada CPO dan komposisi buah restan selama pengolahan, sedangkan data sekunder diperoleh dari arsip perusahaan. Data sekunder ALB diambil dari data Oil Quality di PKS Rambutan. Data yang dianalisis adalah data ALB harian selama 2 bulan sejak Maret-April 2014 kemudian dianalisis menggunakan uji regresi linier berganda dengan data mutu buah dan curah hujan.

Pengaruh mutu buah dan curah hujan terhadap ALB CPO dianalisis dengan uji regresi linier berganda menggunakan sortware Minitab 16. Faktor-faktor yang mempengaruhi ALB adalah mutu buah curah hujan dan penggolahan. Nilai ALB merupakan peubah tak bebas (Y) yang nilainya dipengaruhi oleh beberapa variabel bebas yakni mutu buah under ripe (X1), old crop (X2), over ripe (X3) dan curah hujan (X4). Model yang digunakan dalam analisis ALB CPO kelapa sawit sebagai berikut:

$$
\mathrm{Y}=\beta 0+\beta 1 \mathrm{X} 1+\beta 2 \mathrm{X} 2+\beta 3 \mathrm{X} 3+\beta 4 \mathrm{X} 4+\beta 5 \mathrm{X} 5
$$

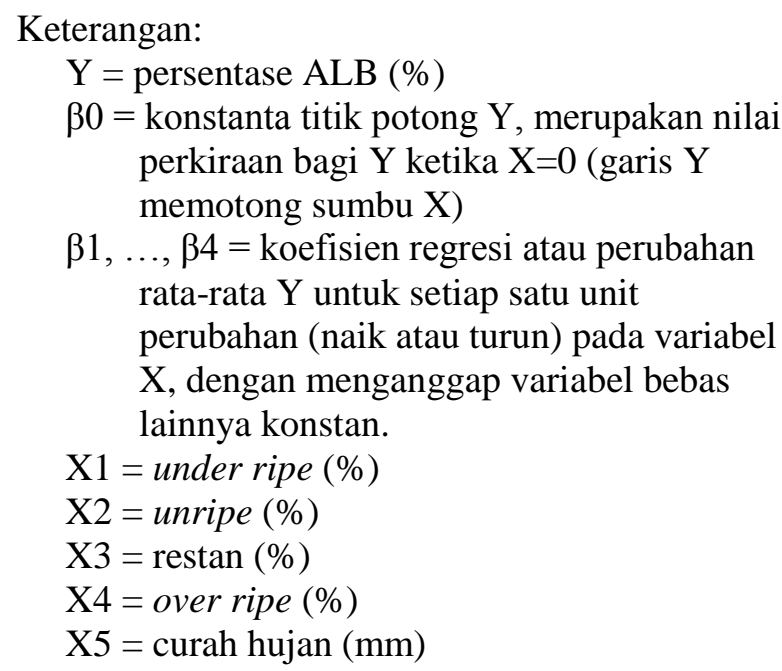

\section{HASIL DAN PEMBAHASAN}

\section{Kriteria Mutu Buah sebagai Dasar Sortasi TBS}

Kriteria mutu buah penting dilakukan untuk memepertahankan mutu CPO yang di hasil PKS. Kriteria buah yang tersortir di sajikan dalam Gambar 1.

Buah yang ditunjukkan pada Gambar 1(A) adalah buat mentah dan abnormal, buah abnormal adalah kelompok buah yang memiliki fruit set yeng rendah atau jumlah buah partenokarpinya lebih banyak daripada buah yang jadi. Buah partenokarpi atau buah tidak sempurna disebabkan karena penyerbukan tidak sempurna atau tidak 
dapat dilakukan karena posisi buah yang terjepit oleh pelepah, sehingga menghasilkan buah dengan kandungan minyak yang rendah serta tidak memiliki cangkang dan endosperm, sedangkan buah mentah merupakan buah yang belum memiliki kriteria matang panen tapi dipaksa dipanen oleh pemanen. Buah mentah jika diolah akan mengalami kesulitan karena buah mentah belum dapat memberondol dengan sempurna saat dilakukan perebusan, sementara itu buah mentah memiliki kandungan rendemen yang masih rendah yaitu 16.0\% (Lubis, 1992).

Buah sakit yang ditunjukkan oleh Gambar 1 (B) adalah buah yang di seluruh permukaannya ditumbuhi organ yang menyerupai tangkai-tangkai kecil sebagai diferensiasi spikelets yang dihasilkan dari abnormalitas inflorescens bunga betina serta kulit yang ditumbuhi oleh jamur. Buah batu yang ditunjukkan oleh Gambar 1 (C) adalah buah yang sudah masuk standar minimal kriteria matang panen tetapi mengalami pengerasan sehingga tidak dapat membrondol. Pengolahan buah yang memiliki kualitas yang buruk akan mempengaruhi kualitas CPO yang dihasilkan oleh pabrik kelapa sawit (PKS). Menurut Fauzi et al. (2012) menyatakan bahwa CPO yang dihasilkan dalam suatu pabrik maksimal memiliki kandungan ALB sebesar 5\% dan KK sebesar $0.15 \%$.
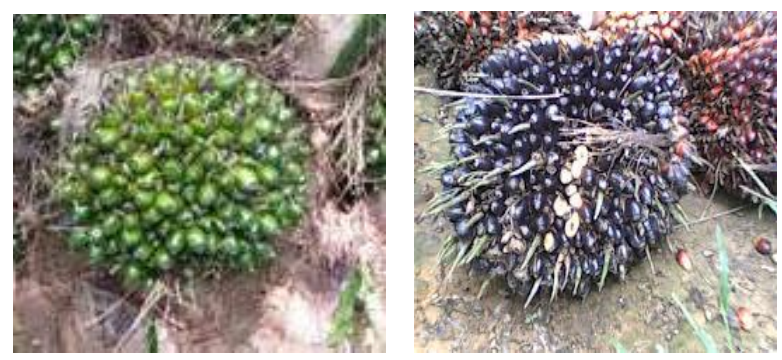

(A)

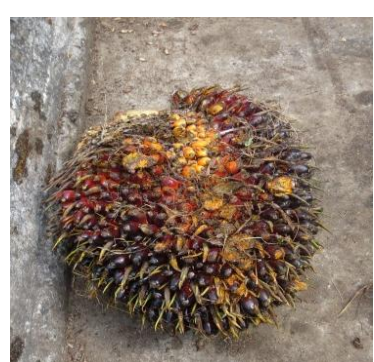

(B)

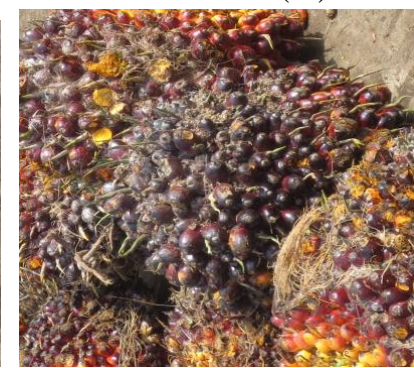

(C)

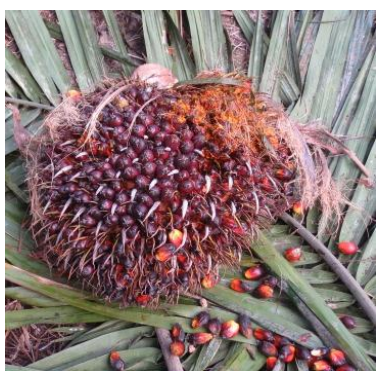

(D)

Gambar 1. TBS yang tidak sehat: Buah mentah dan abnormal (A) Buah sakit (B) Buah batu (C) Buah matang normal (D)

\section{Kualitas Panen}

Panen merupakan pekerjaan memotong buah yang sudah memenuhi kriteria kematangan buah yang sesuai dan mengantarkannya ke pabrik sebanyak-banyaknya dengan cara dan waktu yang tepat, sehingga mengurangi kuantitas produksi. Kualitas panen secara tidak langsung akan mempengaruhi produksi TBS dalam suatu perkebunan kelapa sawit, karena dengan pemanenan yang baik akan memperkecil lossis produksi. Sumber-sumber losses produksi di lapangan adalah potong buah mentah, buah matang tidak dipanen, brondolan tidak dikutip, buah atau brondolan dicuri. Kualitas panen diamati melalui pengamatan mutu hancak. Karakter yang diamati adalah TBS tertinggal. Data pengamatan TBS yang tidak dipanen dilapangan dapat dilihat dalam (Tabel 1).
Tabel 1. Pengamatan TBS tidak dipanen di Afdeling I Kebun Rambutan

\begin{tabular}{ccc}
\hline $\begin{array}{c}\text { No } \\
\text { Pemanen }\end{array}$ & $\begin{array}{c}\text { Tanaman sampel } \\
\text { (tanaman) }\end{array}$ & $\begin{array}{c}\text { TBS tertinggal di } \\
\text { tanaman (TBS) }\end{array}$ \\
\hline 1 & 176 & 4 \\
2 & 166 & 1 \\
3 & 163 & 1 \\
4 & 174 & 3 \\
\hline Total & 679 & 9 \\
\hline Unharvesting bunch (UHB/Palm) & 0.013 \\
\hline
\end{tabular}

Data pada Tabel 1 menunjukkan dari 679 tanaman sampel yang diambil dari 4 orang tenaga pemanen ditemukan buah tertinggal di pohon dengan rata-rata 0.013. Jumlah buah yang tertinggal terbilang masih sangat kecil. Dengan masih ditemukannya TBS yang tertinggal di pohon memperlihatkan bahwa ketelitian dan ketekunan pemanen masih kurang baik, selain itu kondisi 
hancak yang kurang terawat tunasannya menyebabkan pelepah gondrong, sehingga menyulitkan pemanen untuk melihat buah yang matang dan siap panen pada pohon tersebut. Secara tidak langsung banyak atau tidaknya buah matang yang tertinggal di pohon menyebabkan losses produksi, sehingga menyebabkan kerugian terhadap perusahaan. Oleh sebab itu, perlu ditingkatkannya kedisiplinan dan keuletan pemanen sehingga losses yang terjadi di lapangan dapat dikurangi. Pengawasan yang baik dari mandor untuk menjaga kualitas panen juga diperlukan.

\section{Ketersediaan Tenaga Kerja}

Dalam melakukan kegiatan pemanenan kebutuhan tenaga kerja perlu diperhatikan, hal ini penting dilakukan karena ketersediaan tenaga kerja dapat mempengaruhi jumlah produksi TBS harian kebun. Selain itu kebutuhan tenaga panen didasarkan pada efisiensi jumlah tenaga kerja dalam menyelesaikan semua kapvel sesuai dengan rotasi panen yang sudah ditentukan. Untuk menghitung kebutuhah tenaga kerja pemanenan buah digunakan rumus berikut:

\section{Kebutuhan tenaga panen $=\underline{\mathrm{A} \times \mathrm{B} \times \mathrm{C} \times \mathrm{D}}$ \\ $\mathrm{E}$}

Keterangan:

$\mathrm{A}=$ luas hanca (kapvel) yang akan di panen (ha)

$\mathrm{B}=$ Kerapatan panen

$\mathrm{C}=$ Rata-rata berat buah (camidal) $(\mathrm{kg})$

$\mathrm{D}=$ Populasi tanaman $/$ ha

$\mathrm{E}=$ kapasitas panen $/ \mathrm{HK}$

TM muda (Tahun tanam 2006) dengan luas hanca sebesar 213.3 ha, memiliki kerapatan panen sebanyak 1:5 dengan bobot rata-rata buah $11 \mathrm{~kg}$, dan kapasitas panen $1800 \mathrm{~kg}$, jumlah populasi 143 pohon/ha. Maka kebutuhan tenaga panen yang harus disediakan untuk TM 2006 adalah:

Kebutuhan tenaga panen

$$
\begin{aligned}
& =\frac{213.1 \mathrm{ha} \times(1: 5) \times 11 \mathrm{~kg} \times 143 \text { pohon } / \mathrm{ha}}{1800 \mathrm{~kg} / \mathrm{HK}} \\
& =37 \mathrm{pemanen} / \text { hari kerja }
\end{aligned}
$$

Jumlah tenaga pemanen yang ideal untuk TM 2006 adalah 34 orang. Jumlah tenaga panen TM 2006 yang tersedia adalah 10 berarti tenaga pemanen masih kurang sebanyak 27 orang. Kekurangan tenaga pemanen akan mengakibatkan dalam penyelesaian hanca panen. Jika hanca panen harian tidak terselesaikan akan mengakibatkan rotasi panen yang terlambat. Hal ini akan menyebabkan semakin bertambahnya buah yang over ripe. Pada dasarnya buah yang over ripe pada dasarnya mengadung kadar ALB yang tinggi sehingga dapat menurunkan kualitas CPO yang dihasilkan.

\section{Pengaruh Mutu Buah dan Curah Hujan terhadap $A L B$}

Penggolahan TBS yang memiliki mutu yang buruk dapat mempengaruhi kualitas CPO rendah. Ciri CPO yang memiliki kualitas rendah dapat dilihat dari kandungan ALB yang tinggi. Asam lemak bebas yang tinggi akan menyebabkan minyak mudah membeku pada suhu kamar sehingga menyulitkan dalam tranportasi minyak. Selain itu, CPO yang memiliki kandungan ALB tinggi memiliki nilai harga yang lebih rendah.

Buah kelapa sawit yang sudah matang dan masih segar hanya mengandung $0.1 \%$ asam lemak bebas, tetapi buah-buah yang sudah memar atau pecah dapat mengandung asam lemak bebas sampai 50\%. Buah yang dibiarkan begitu saja tanpa perlakuan khusus, akan memiliki kandungan asam lemak bebas mencapai $67 \%$ dalam waktu 24 jam. Untuk membatasi terbentuknya asam lemak bebas, buah kelapa sawit harus segera dipanasi dengan suhu antara $90-100^{\circ} \mathrm{C}$ (Setyamidjaja, 2006).

Kegiatan sortasi yang dilakukan di PKS Rambutan bertujuan untuk mengurangi kerugian pabrik akibat pengolahan buah yang bermutu buruk. Teknis penyortiran di stasiun sortir dengan memeriksa setiap truk yang akan masuk ke loading ramp. Kemudian buah yang tersortir dikelompokkan sesuai dengan kelas mutu. Peramalan pengaruh mutu buah terhadap ALB dapat dijelaskan pada persamaan berikut.

$$
\begin{aligned}
\% \text { ALB }= & 2.579+0.046 \text { Unripe }-0.004 \text { Under } \\
& \text { ripe }+0.001 \text { Restan }+0.029 \text { Over ripe } \\
& +0.001 \text { curah hujan }
\end{aligned}
$$

Autokorelasi dapat dilihat dari nilai Durbin Watson (DW) pada output minitab. Nilai DW <-2 menunjukkan adanya autokorelasi positif dan jika $>2$ menunjukkan autokorelasi negatif, sedangkan apabila nilai terletak antara $-2 \leq \mathrm{DW} \leq 2$ maka tidak terdapat autokorelasi (Santoso, 2000).

Berdasarkan teori di atas dapat disimpulan bahwa tidak ada hubungan autokorelasi atara variabel yang diduga dengan kandungan ALB. Multikolinieritas dapat dilihat dari nilai Varianc Inflation Factor (VIF). Batas toleransi yang dapat diterima adalah nilai VIF < 10 (Tabel 2). 
Tabel 2. Hasil pendugaan faktor mutu buah dan terhadap ALB

\begin{tabular}{lrcl}
\hline Variable & Koefisien & Nilai signifikasi & VIF \\
\hline Unripe (X1) & 0.046 & $0.326^{\mathrm{TN}}$ & 1.115 \\
Under ripe $(\mathrm{X} 2)$ & -0.004 & $0.903^{\mathrm{TN}}$ & 1.113 \\
Over ripe (X3) & 0.029 & $0.568^{\mathrm{TN}}$ & 1.035 \\
Restan (X4) & 0.001 & $0.087^{*}$ & 1.069 \\
curah hujan (X5) & 0.001 & $0.433^{\mathrm{TN}}$ & 1.032 \\
Intersep & 2.579 & & \\
\hline Durbin Watson & 0.527 \\
\hline \multicolumn{4}{l}{ Keterangan: *= Berbeda nyata pada taraf $10 \%, \mathrm{TN}=$ Tidak } \\
\multicolumn{4}{l}{ nyata, VIF = Variance inflasion factor }
\end{tabular}

Kenaikan persentase buah restan berpengaruh nyata $(\mathrm{P}$ value $=0.087)$ terhadap kenaikan kadar ALB pada taraf $10 \%$. Kenaikan $1 \%(\mathrm{~kg})$ buah restan akan menaikkan ALB sebesar $0.001 \%$ dengan asumsi faktor lain dianggap konstan. Hasil lain menunjukkan bahwa buah over ripe, buah unripe dan buah under ripe memberikan pengaruh tidak nyata terhadap kenaikan ALB. Hasil analisis regresi berganda linier terhadap pendugaan nilai ALB berdasarkan pengukuran terhadap faktor yang mempengaruhi ALB didapat nilai $\mathrm{R}^{2}$ sebesar $10.1 \%$. Artinya mutu buah dan curah hujan berpengaruh sebesar $10.3 \%$ terhadap kenaikan ALB dan sekitar 89.9\% kenaikan dipengaruhi oleh faktor lain yang tidak dianalisis dalam model.

Curah hujan yang tinggi berdampak positif bagi pertumbuhan tanaman dan produksivitas kelapa sawit. Curah hujan yang ideal untuk tanaman kelapa sawit adalah $2000-2500 \mathrm{~mm}$ per tahun dan tersebar merata sepanjang tahun (Sunarko, 2007). Secara statistik, curah hujan belum mempengaruhi kandungan ALB CPO secara signifikan namun dampak yang diberikan besar terhadap transportasi dan pengangkutan TBS. Curah hujan yang tinggi akan menyebabkan TBS yang diolah mengandung kadar air tinggi, sehingga perkembangbiakan mikroorganisme penghidrolisis minyak menjadi tinggi dapat menghambat kegiatan pemanenan dan pengangkutan buah. Terhambatnya panen dan pengangkutan buah dapat meningkatkan losses produksi di lapangan. Keterlambatan pemanenan dapat meningkatkan jumlah buah over ripe yang berdampak pada kenaikan ALB. Sedangkan keterlambatan pengangkutan TBS akan meningkatkan persentase TBS restan yang berdampak pula pada kenaikan ALB.

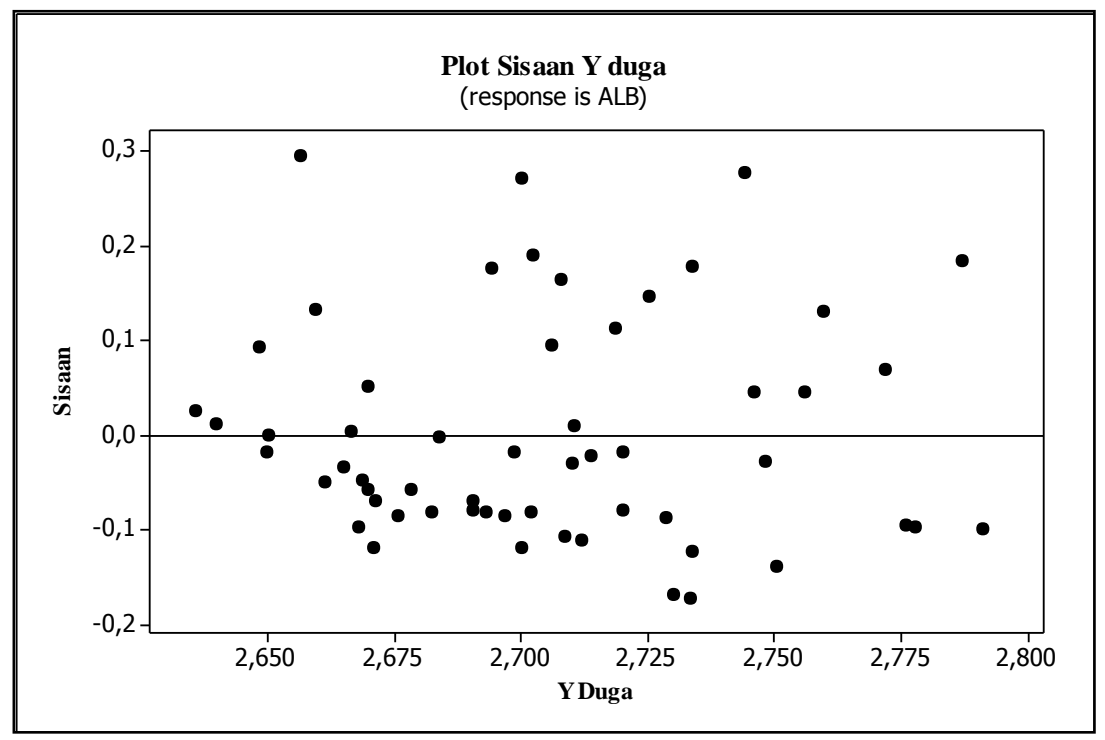

Gambar 2. Pola sebaran grafik sisaan terhadap Y duga

Gambar 2 menunjukkan bahwa penyebaran nilai sisaan $\mathrm{Y}$ duga terhadap ALB membentuk pola heteroskedastisitas dimana nilai keragamannya besar. Model tersebut menunjukkan bahwa model yang dipakai tidak sepenuhnya tepat. Hal tersebut berarti variabel yang diamati masih sulit untuk disimpulkan adanya faktor utama yang mempegaruhi kadar ALB.

Kenaikan kandungan ALB dapat dipengaruhi oleh pelukaan buah. Buah yang mengalami pelukaan atau memar akan membawa lebih banyak kotoran dan tanah, sehingga buah terkontaminasi oleh mikroorganisme. Pembentukan FFA dalam buah dimulai dengan pecahnya dinding sel yang mengandung minyak, sehingga enzim lipolitik yang terdapat pada protoplasma bekerja menghidrolisis lemak dan asam lemak akhirnya dibebaskan (FFA terbentuk). Reaksi tersebut akan berlangsung sangat cepat, akan tetapi pada buah yang tidak luka FFA hanya naik $0.2 \%$ selama 4 hari (Mangoensoekarjo dan Semangun, 2003). 
Penggunaan alat panen yang kurang bijak adalah salah satu penyebab buah luka karena penanganan panen yang kasar. Pohon kelapa sawit yang semakin tinggi akan menyulitkan penggunaan dodos dalam menjangkau buah, sehingga potensi adanya buah luka lebih besar. Selain itu buah luka juga diakibatkan karena buah yang busuk atau sakit. Buah sakit disebabkan karena aktivitas mikroorganisme seperti bakteri dan cendawan.

\section{KESIMPULAN}

CPO yang berkualitas dapat diperoleh dengan manajemen panen yang baik. Indikator mutu CPO baik adalah memiliki kandungan ALB yang rendah. Presentase kadar ALB pada CPO salah satunya dipengaruhi oleh mutu buah. Hasil analisis menunjukkan bahwa buah over ripe, buah under ripe dan buah unripe memberikan pengaruh tidak nyata terhadap kenaikan ALB. Kenaikan persentase buah restan berpengaruh nyata terhadap kenaikan kadar ALB. Setiap kenaikan $1 \%$ buah restan akan menikkan ALB sebesar $0.001 \%$ dengan asumsi faktor lain dianggap kosntan. Penggunaan data untuk pembuatan model linier regresi berganda sebaiknya menggunakan data dengan selang waktu yang lebih lama ( $\geq 1$ tahun) agar analisis yang dihasilkan lebih tepat.

\section{DAFTAR PUSTAKA}

Fauzi, Y., Widyastuti, Y.E., Iman, S., Hartono, R. 2012. Kelapa sawit: Budidaya, Pemanfaatan Hasil dan Limbah, Analisis Usaha dan Pemasaran. Jakarta(ID): Penebar Swadaya.
Hasibuan, A., Nuryanto, E. 2011. Kajian Kandungan $\mathrm{P}, \mathrm{Fe}, \mathrm{Cu}$, dan $\mathrm{Ni}$ pada Minyak Sawit, Minyak Inti Sawit dan Minyak Kelapa Selama Proses Rafinasi. Jurnal Standardisasi.13(1): 67 - 71.

Lubis, A.U. 1992. Kelapa Sawit (Elais guineensis Jacq.) di Indonesia. Pusat Penelitian Kelapa Sawit. Medan.

Mangoensoekarjo, S., Semangun, H. 2003. Manajemen Agrobisnis Kelapa Sawit. Gadjah Mada University Press. Yogyakarta. 605 hal.

Santoso, S. 2000. Buku Latihan SPSS Statistik Parametrik. Jakarta (ID): Elex Media Komputindo.

Setyamidjaja, D. 2006. Kelapa Sawit. Yogyakarta(ID): Kanisius.

Sastrosayono, S. 2003. Budi Daya Kelapa Sawit. Jakarta(ID). Agromedia Pustaka

Sunarko. 2007. Petunjuk Praktis Budidaya dan Pengolahan Kelapa Sawit. Jakarta (ID): Agromedia Pustaka. 